\title{
ОЖИРІННЯ ЯК СОЦІАЛЬНА ПРОБЛЕМА СУЧАСНОСТІ
}

\author{
А. О. Матвейчева, В. Я. Пушкін, Р. Р. Осінчук, С. Р. Касіян \\ Миколаӥвська обласна офтальмологічна лікарня \\ ДВНЗ «Тернопільський держсавний медичний університет \\ імені І. Я. Горбачевського Моз Украӥни»
}

\begin{abstract}
У статті проаналізовано захворюваність на поєднаний перебіг аліментарного ожиріння. Встановлено, що аліментарне ожиріння в населення Тернопільської області найчастіше поєднується з ендокринною патологією, зокрема, з цукровим діабетом 2 типу (в 62,7 \% хворих) та кардіологічною патологією, а саме з гіпертонічною хворобою (34,3 \% пацієнтів), при цьому в гендерному аспекті частіше на поєднані патології хворіють жінки. Отримані результати свідчать про те, що аліментарне ожиріння призводить до формування несприятливого тла для перебігу основної хвороби.
\end{abstract}

\section{OBESITY AS SOCIAL PROBLEM OF NOWADAYS}

\section{A. O. Matveycheva, V. Ya. Pushkin, R. R. Osinchuk, S. R. Kasiyan}

\author{
Mykolayiv Regional Ophthalmology Hospital \\ SHEI «Ternopil State Medical University by I. Ya. Horbachevsky of MPH of Ukraine»
}

The article analyzes the combined incidence course alimentary obesity. It was established that alimentary obesity in the population of Ternopil region often combined with endocrine disorders, including diabetes mellitus type 2 (in $62.7 \%$ of patients) and cardiac pathology, namely hypertension (34.3\% patients), while in gender aspect woman more often had comorbidity pathology. The results indicate that alimentary obesity contributes to an unfavorable background for the main course of the disease.

Вступ. Однією з важливих проблем сучасного суспільства єпроблема ожиріння, оскільки надмірна маса тіла спостерігається майже у половини дорослого і в близько $15 \%$ дитячого населення в економічно розвинених країнах [1, 2]. За даними Всесвітньої організації охорони здоров'я, надмірну масу тіла до кінця XX століття мало близько 30 \% жителів нашої планети, зазначаючи, що ця проблема торкнулася всіх верств населення, незалежно від соціальної і професійної приналежності, віку, місця проживання і статі. Лідером за поширеністю ожиріння є США, де надмірна маса відзначається у $60 \%$ населення, ожиріння -у $27 \%$. Варто зазначити, що ожиріння характеризується надлишковим накопиченням жирової тканини ворганізмі: у чоловіків більше 10-15\%, у жінок - понад 20-25 \% від маси тіла [3].

Безперечною причиною ожиріння більшість науковців вважає сучасний стиль харчування, неоднозначно при цьому оцінюючи роль жирів і вуглеводів у раціоні, щоденного споживання певної кількості калоpin̆. Rolls B. в опублікованих результатах дослідження стверджує, що розміри порцій в місцях громадського харчування Америки зростають, перевищуючи вже

(ㄱ А. О. Матвейчева, В. Я. Пушкін, Р. Р. Осінчук, С. Р. Касіян, 2015 рекомендовані розміри, розроблені US Department of Agriculture Food Guide Pyramid і це, на його думку, $є$ основним вирішальним факторому розвитку ожиріння [4, 5]. За даними численних досліджень, що вивчають вплив надмірної маси на здоров'я людини, було встановлено, що більше 90 \% відомих захворювань виникали на тлі ожиріння. Так у людей, які мають надмірну масу, в 3 рази частіше діагностують захворювання серцевосудинної системи (гіпертонічна хвороба, ішемічна хвороба серця, інсульти), у 80 \% пацієнтів із надмірною масою діагностують супутній інсулінонезалежний цукровий діабет, практично всі хворі на ожиріння мають проблемиз опорно-руховим апаратом (остеохондрози, артрити, артрози, остеопороз тощо).

Тому метою нашого дослідження було проаналізувати захворюваність на поєднаний перебіг аліментарного ожиріння та хвороб серцево-судинної, гастроентерологічної та ендокринної систем.

Основна частина. Проведено експертну оцінку 900 історій хвороб пацієнтів з аліментарним ожирінням (по 300 історій хвороб з кардіологічного, ендокринологічного та гастроентерологічного відділень), які протягом календарного 2014 року перебували на стаціонарному лікуванні в КЗ ТОР «Тернопільська університетська 
лікарня». Тяжкість ожиріння оцінювали з урахуванням критеріїв International Diabetes Federation (IDF, 2005р.) на підставі визначення індексу маси тіла (IMT), який розраховували за формулою Кетле: IMT=маса тіла (Кг)/зріст (M²). Варто відмітити, що найчастіше діагноз «аліментарне ожиріння» не був зазначений у заключному діагнозі.

Статистичну обробку отриманих результатів проводили наперсональному комп'ютері за допомогою ліцензійних програм «Microsoft Exce|» та «Statistica 6.0».
Отримані результати свідчать про те, що аліментарне ожиріння призводить до формування несприятливого тла для перебігу основної хвороби. Так, серед 300 історій хвороб пацієнтів кардіологічного відділення найчастіше аліментарне ожиріння поєднувалося у хворих із гіпертонічною хворобою у жінок (68 пацієнток). Варто відзначити, що ішемічну хворобу серця (IXC) у поєднанні з ожирінням теж з більшою частотою діагностували в жінок (рис. 1).

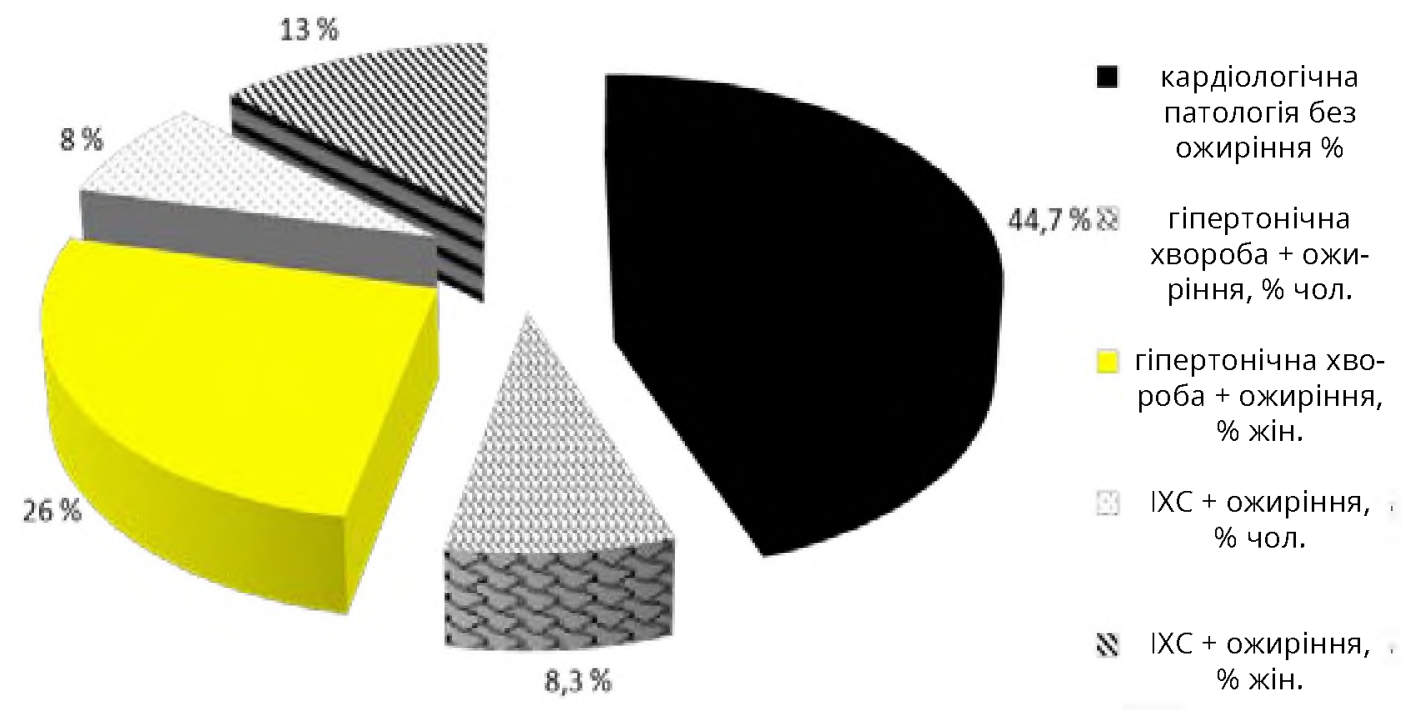

РUС. 1. Поєднаний перебіг аліментарного ожиріння та хвороб серцево-судинної системи.

Аналіз історій хвороб пацієнтів гастроентерологічного відділення свідчив про те, що аліментарне ожиріння найчастіше поєднувалося із захворюваннями гепатобіліарного тракту, зокрема, з хронічним холециститом і жовчнокам'яною хворобою (18,2\%), і пептичною виразкою (13,0%). На відміну від кардіологічної патології, у пацієнтів гастроентерологічного відділення не виявлено значимої гендерної розбіжності (рис. 2). Слід зазначити, що аліментарне ожиріння частіше поєднувалося у пацієнтів із серцевосудинною патологією на противагу отриманих даних, які стосуються гастроентерологічної патології (55,3\% проти 31,3\%).

Аналіз історій хвороб пацієнтів ендокринологічного відділення свідчив про те, що аліментарне ожиріння найчастіше поєднувалося з цукровим діабетом 2 типу (ЦД, тип 2) (45,3\%), при цьому ожиріння у жінок переважало на 10,7 \% (рис. 3). Порівнюючи відсоток поєднаної патології встановлено, що у хворих ендокринного профілю найчастіше виявляється аліментарне ожиріння. Такий висновок збігається 3 даними Л. М. Пасієшвілі і М. В. Моргуліс [6], які довели, що в патогенезі ожиріння важливе місце займають гормональні зміни, насамперед, інсулярного апарату підшлункової залози. При більшості форм ожиріння такі зміни відбуваються тривалий час, їм притаманні гіперінсулінізм та резистентність тканин до інсуліну.

якщо узагальнити отримані результати, можна зробити такий висновок: частота аліментарного ожирінняу пацієнтів терапевтичного профілюв вередньому складає 44,0%, при цьому найбільше хворих із поєднаною патологією виявлено у кардіологічному відділенні. У жінок з патологією серцево-судинної й ендокринної систем частіше діагностують аліментарне ожиріння.

Такий, на нашу думку, великий відсоток пацієнтів 3 аліментарним ожирінням, змусивпроаналізувати дані літератури. Результати досліджень Л. М. Пасієшвілі та співавт. з Харківського національного медичного університету свідчать про те, що аліментарне ожиріння спостерігається у 26,0 \% пацієнтів [6]. Таку розбіжність можна пояснити таким чином: насамперед, ми аналізували історії хвороб лише 3 відділень, де передбачали більшу частоту аліментарного ожиріння, 


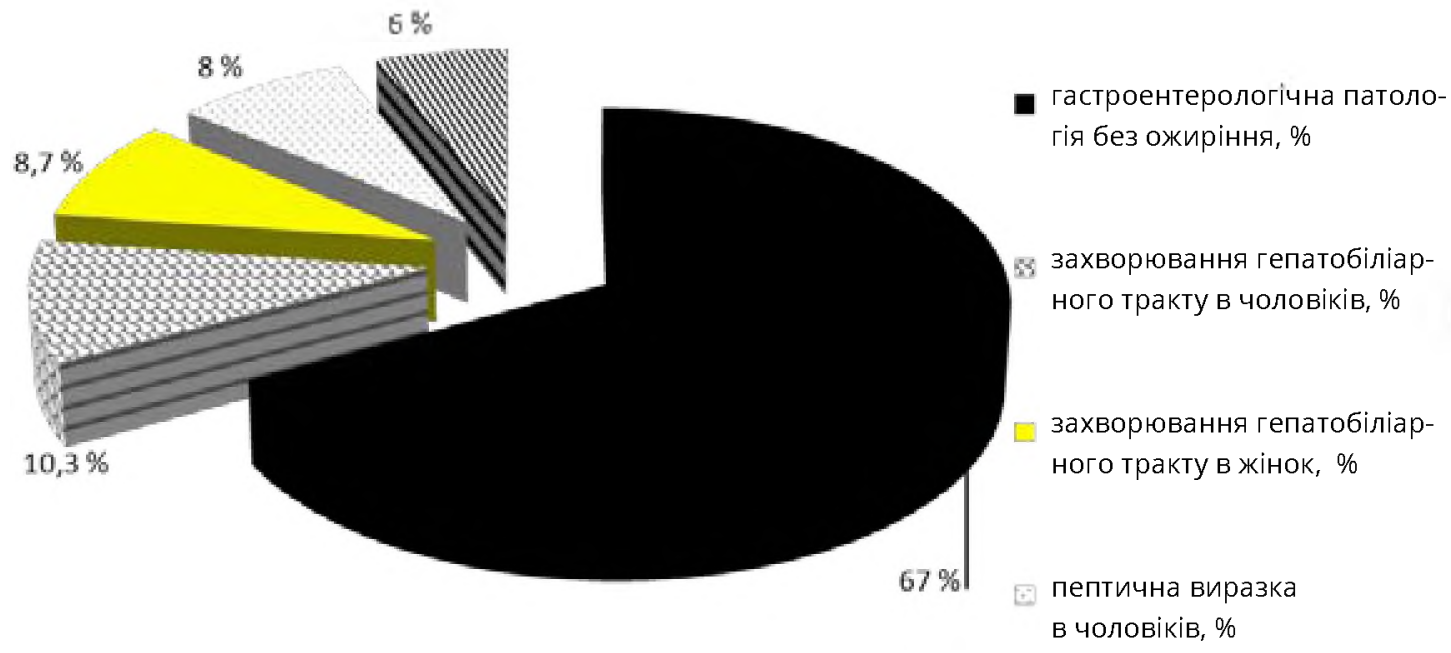

\$. пептична виразка в жінок, \%

РИс. 2. Поєднаний перебіг аліментарного ожиріння і гастроентерологічної патології.

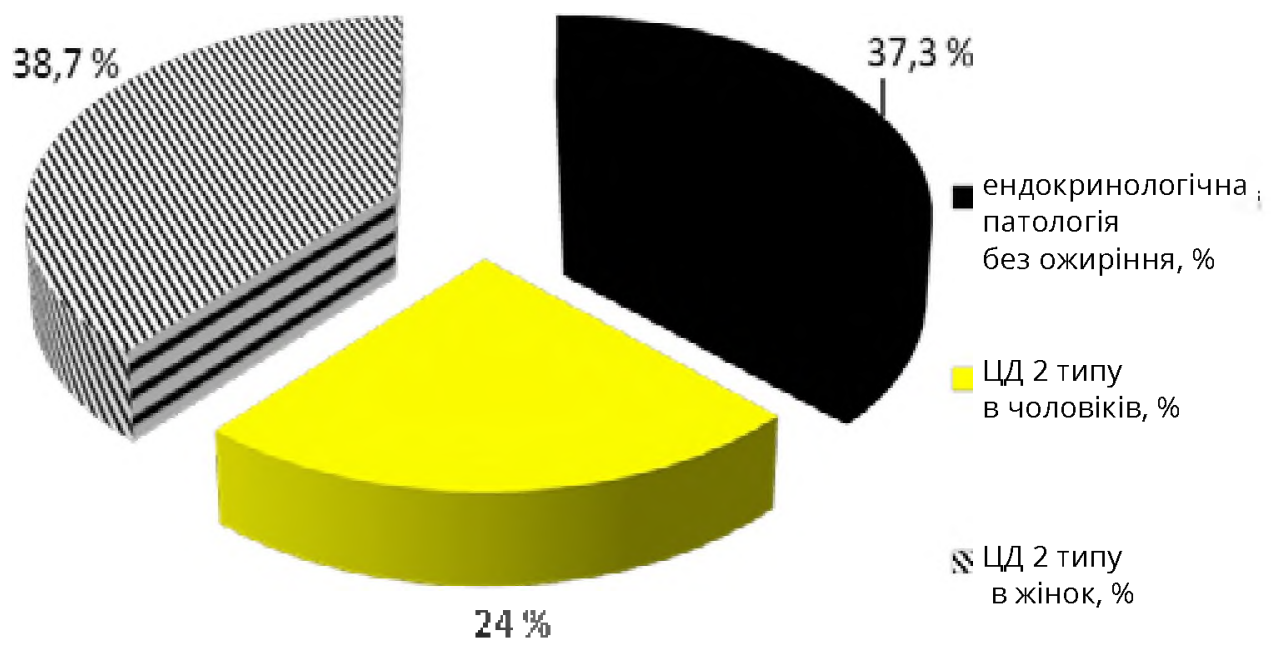

РИС. 3. Поєднаний перебіг аліментарного ожиріння і захворювань ендокринної системи.

іншою причиною різниці упоказниках можуть бути не завжди коректні дані маси і зросту пацієнтів в історіях хвороб. Великий відсоток осіб з надмірною масою тіла в Тернопільській області також можна обґрунтувати недостатнім забезпеченням йодом місцевого населення у результаті зниженого його вмісту у воді та ґрунті.

Загальновідомо, що аліментарне ожиріння впливає на якість і тривалість життя населення, особливо при поєднанні з хворобами внутрішніх органів. 3 огляду на це високий рівень аліментарного ожиріння мав би супроводжуватися зниженням тривалості життя населення Тернопільської області. У дослідженні Л. А. Чепелевської та співавт. зазначено, що наша область належить до групи з відносно високими по- казниками тривалості життя, які перевищують загальноукраїнські показники на 3-4 роки у чоловіків і 22,5 року - в жінок [7]. з цього випливає, що аліментарне ожиріння не виступає основним фактором смертності населення. Можливо, певний відсоток жирової тканини виступає протекторним фактором прогресування захворювання, забезпечує мобілізацію певних структур організму. У роботі А. В. Петрова зазначено, що негативний вплив ожиріння на показники якості життя у пацієнтів з ЦД, тип 2 найбільш значимо виявляється при невеликій тривалості діабету, і роль ожиріння зменшується при його прогресуванні [8]. Виходячи з отриманих результатів і даних літератури, можна розглядати аліментарне ожиріння як фактор 
ризику розвитку захворювань, проте його внесок у прогресування патології і відсоток смертності від наслідків хвороби $є$ невеликим.

Висновок. Аліментарне ожиріння в населення Тернопільської області найчастіше поєднується з ендо-

\section{ЛІТЕРАТУРА}

1. Белоусов Ю. Б. Артериальная гипертензия и ожирение: принципы рациональной терапии / Ю. Б. Белоусов, К. Г. Гуревич // Consilium Medicum. - № 9. - C. 528-534.

2. Бессесен Д. Г. Избыточный вес и ожирение. Профилактика, диагностика и лечение / Д. Г. Бессесен, Р. Кушнер. - М. : ЗАО «Издательство БИНОМ». - 240 с.

3. Мельниченко Г. А. Ожирение: эпидемиология, классификация, патогенез, клиническая симптоматика и диагностика / Г. А. Мельниченко, Т. И. Романцова // Ожирение: этиология, патогенез, клинические аспекты ; под ред. И. И. Дедова, Г. А. Мельниченко. - М. : ООО «Медицинское информационное агентство», 2006. Гл. 1. - С. 16-42.

4. Livingstone B. Epidemiology of childhood obesity in Europe / B. Livingstone // Eur. J. Pediatr. - 2000. - № 1. P. 14-34. кринною патологією, зокрема, з цукровим діабетом 2 типу (в 62,7\% хворих) та кардіологічною патологією, а саме з гіпертонічною хворобою (34,3\% пацієнтів), при цьому в гендерному аспекті частіше на поєднані патології хворіють жінки.

5. Schmidt C.W. Obesity / C. W. Schmidt// Environmental Health Perspectives. - 2003. - № 13. - P. 700-707.

6. Пасієшвілі Л. М. Роль кальцію в формуванні клініколабораторних синдромів при різних варіантах хронічного панкреатиту / Л. М. Пасієшвілі, М. В. Моргуліс // Сучасна гастроентерологія. - 2006. - № 4 (30). - С. 31-34.

7. Чепелевська Л. А. Середня очікувана тривалість життя як критерій медико-демографічної ситуації в Україні / Л. А. Чепелевська, О. П. Рудницький // Вісник соціальної гігієни та організації охорони здоров'я України. - 2014. № 2 (60). - С. 39-43.

8. Петров А. В. Влияние ожирения на качество жизни женщин, больных сахарным диабетом 2-го типа / А. В. Петрова // Международный эндокринологический журнал. -2009. - № 2 (20). - http://www.mif-ua.com/archive/ article/8755 